\title{
Eight New Serotypes of Arizona arizonae Kauffmann and Edwards
}

\author{
BILLIE O. BLACKBURN, LOIS V. NELSON, and VELMA L. KARNS
}

\begin{abstract}
Diagnostic Bacteriology Section, Veterinary Services, Animal and Plant Health Inspection Service, National Animal Disease Laboratory, Ames, Iowa 50010, and State-Federal Animal Disease Laboratory, Phoenix, Arizona 85007
\end{abstract}

Eight new serotypes of Arizona arizonae Kauffmann and Edwards (syn.: Arizona hinshawii Ewing) were characterized biochemically and serologically. The biochemical reactions of these serotypes were typical of the genus. The antigenic formulas determined serologically were $1,4: 16,17,18 ; 5: 1,6,7 ; 6: 1,78$; $10 \mathrm{a}, 10 \mathrm{~b}: 16,17,18 ; 19: 17,20 ; 22: 1,3,11 ; 24: 33: 28$; and $28: 29: 31$.

The arizonae are members of the family Enterobacteriaceae and are closely related to the salmonellae and the citrobacters. Like the salmonellae, the arizonae apparently have no host barriers and are widely distributed. Farm animals from which most arizonae from the United States have been isolated are turkeys chickens, and sheep. Isolations from reptiles and amphibians have also been common. Strains from some of the abovementioned hosts were received by the Serotyping Laboratories of the Animal and Plant Health Inspection Service, U.S. Department of Agriculture, for identification. Eight of the strains received were identified as belonging to new serotypes, which are described herein.

Bacterial strains. The eight strains reported here were identified as belonging to Arizona arizonae Kauffmann and Edwards (5) (syn.: $A$. hinshawii Ewing (2)). Four of the strains were isolated from different animals on one farm as follows: strain 921 from a horned toad, strain 970 from a lizard, strain 1035 from a snake, and strain 1099 from a ground squirrel. The isolations were made during a survey to identify possible reservoirs of arizonae that were infecting turkeys on the farm.

Strain 71 was isolated from chickens 3 weeks of age. It was recovered from four of five chicks submitted to the laboratory and was considered the cause of a $1 \%$ mortality in a flock of 18,000 birds.

Strain 79R was isolated from a western diamondback rattlesnake (Crotalus atrox), and strain 184 was from a rubber boa snake (Charina bottae bottae). These snakes were zoo animals, and their state of health was not reported.
Strain 766 was isolated from a water snake (Natrix sipedon) during a study of the snake's intestinal flora.

Biochemical media and procedures. The biochemical media used and the test procedures that were followed were described previously by Ewing and Davis (3).

Serological procedures. The antigen preparation, tube agglutination tests, and antibody absorption procedures used were those described by Edwards and Ewing (1).

Each of the eight strains was a gram-negative, asporogenous, rod-shaped, peritrichously flagellated bacterium. With minor exceptions, the biochemical reactions of the eight strains were typical of those obtained with a majority of the members of the genus Arizona (4). They failed to produce indole, were methyl-red positive and Voges-Proskauer negative, grew on Simmon citrate medium, and produced hydrogen sulfide in triple sugar iron agar. They produced lysine and ornithine decarboxylases and arginine dihydrolase but did not produce urease or phenylalanine deaminase. They liquefied gelatin after 3 or more days of incubation, reduced nitrates to nitrites, and failed to grow in potassium cyanide medium. Glucose was fermented with the production of acid and gas within $24 \mathrm{~h}$. Mannitol, arabinose, maltose, xylose, trehalose, and glycerol were fermented. Sucrose, salicin, dulcitol, adonitol, inositol, and raffinose were not fermented. Mucate and sodium malonate were utilized, and tests for $\beta$-D-galactosidase activity (ONPG test) were positive. Additional tests which did not give the same results with each strain are listed in Table 1. These results show that these strains belong to Arizona arizonae. Results of the serological 
TABLE 1. Biochemical test results which varied for the eight new Arizona serotypes ${ }^{a}$

\begin{tabular}{|c|c|c|c|c|c|c|c|c|}
\hline \multirow[b]{2}{*}{ Substrate } & \multicolumn{8}{|c|}{ Strain } \\
\hline & 1035 & 921 & 970 & 1099 & 71 & $79 \mathrm{R}$ & 184 & 766 \\
\hline Lactose & $(+)$ & $(+)$ & - & $(+)$ & + & - & + & + \\
\hline Sorbitol & $(+)$ & + & + & + & + & + & + & $(t)$ \\
\hline Cellobiose & - & - & - & $(+)$ & - & - & - & - \\
\hline $\begin{array}{l}\text { Jordan's tartrate } \\
\text { Organic acids } b\end{array}$ & - & - & - & - & - & - & - & + \\
\hline Citrate & + & + & + & + & + & - & + & + \\
\hline D-tartrate & - & - & - & - & - & - & $(+)$ & $(+)$ \\
\hline I-tartrate & - & - & - & - & - & - & - & - \\
\hline L-tartrate & - & - & - & - & - & - & - & $(+)$ \\
\hline
\end{tabular}

$a+$, Positive after 1 or 2 days of incubation; $(+)$, positive within 30 days; -, negative for 30 days.

${ }^{b}$ Method of Kauffmann and Peterson (6).

TABLE 2. Analysis of $O$ antigens of eight new Arizona serotypes

\begin{tabular}{|c|c|c|c|}
\hline Strain & Serum & $\begin{array}{l}\text { Homologous } \\
\text { titer }\end{array}$ & $\begin{array}{c}\text { New serotype } \\
\text { titer }\end{array}$ \\
\hline 1035 & $\begin{array}{ll}\text { O } & 1,4(292-53)^{a} \\
\text { O } & 1,4 \text { absorbed by } 1035\end{array}$ & $\begin{array}{c}1,280^{b} \\
40\end{array}$ & $\begin{array}{r}1,280 \\
<20\end{array}$ \\
\hline 921 & $\begin{array}{l}\text { O } 6(\mathrm{~S} 050) \\
\text { O } 6 \text { absorbed by } 921\end{array}$ & $\begin{array}{l}640 \\
<20\end{array}$ & $\begin{array}{r}1280 \\
<20\end{array}$ \\
\hline 970 & $\begin{array}{l}10 a, 10 b(3970-53) \\
010 a, 10 b \text { absorbed by } 970\end{array}$ & $\begin{array}{r}1,280 \\
<20\end{array}$ & $\begin{array}{r}1,280 \\
<20\end{array}$ \\
\hline 1099 & $\begin{array}{l}\text { O } 19 \text { (PC 145) } \\
\text { O } 19 \text { absorbed by } 1099\end{array}$ & $\begin{array}{r}320 \\
<20\end{array}$ & $\begin{array}{l}320 \\
<20\end{array}$ \\
\hline 71 & $\begin{array}{l}\text { O } 5(1840-54) \\
\text { O } 5 \text { absorbed by } 71\end{array}$ & $\begin{array}{r}1,280 \\
40\end{array}$ & $\begin{array}{r}1,280 \\
20\end{array}$ \\
\hline $79 \mathrm{R}$ & $\begin{array}{l}\text { O } 22(2959-55) \\
\text { O } 22 \text { absorbed by } 79 R\end{array}$ & $\begin{array}{r}5,120 \\
20\end{array}$ & $\begin{array}{r}5,120 \\
<20\end{array}$ \\
\hline 184 & $\begin{array}{l}\text { O } 28(3592-56) \\
\text { O } 28 \text { absorbed by } 184\end{array}$ & $\begin{array}{r}2,560 \\
20\end{array}$ & $\begin{array}{r}2,560 \\
20\end{array}$ \\
\hline 766 & $\begin{array}{l}\text { O } 24 \text { (PC 196) } \\
\text { O } 24 \text { absorbed by } 766\end{array}$ & $\begin{array}{r}1,280 \\
<20\end{array}$ & $\begin{array}{r}2,560 \\
<20\end{array}$ \\
\hline
\end{tabular}

${ }^{a}$ Parentheses enclose the identification number of the homologous strain.

$b$ Titer is expressed as the reciprocal of the dilution of antiserum giving a definite agglutination. 
TABLE 3. Analysis of $H$ antigens of eight new Arizona serotypes

\begin{tabular}{|c|c|c|c|}
\hline Strain & Serum & $\begin{array}{c}\text { Homologous } \\
\text { titer }\end{array}$ & $\begin{array}{l}\text { New serotype } \\
\text { titer }\end{array}$ \\
\hline 1035 & $\begin{array}{l}\text { H } 16,17,18 \text { (Ore. } 181)^{a} \\
\text { H } 16,17,18 \text { absorbed by } 1035\end{array}$ & $\begin{array}{l}10,240^{b} \\
<20\end{array}$ & $\begin{array}{r}20,480 \\
<20\end{array}$ \\
\hline 921 & $\begin{array}{l}\text { H } 1,7,8 \text { (CDA } 1-184) \\
\text { H } 1,7,8 \text { absorbed by } 921\end{array}$ & $\begin{array}{r}20,480 \\
<20\end{array}$ & $\begin{array}{r}10,240 \\
<20\end{array}$ \\
\hline 970 & $\begin{array}{l}\text { H } 16,17,18 \text { (Ore. } 181) \\
\text { H } 16,17,18 \text { absorbed by } 970\end{array}$ & $\begin{array}{r}10,240 \\
<20\end{array}$ & $\begin{array}{r}20,480 \\
<20\end{array}$ \\
\hline 1099 & $\begin{array}{l}\text { H } 17,20 \text { (PC107) } \\
\text { H } 17,20 \text { absorbed by } 1099\end{array}$ & $\begin{array}{r}10,240 \\
<20\end{array}$ & $\begin{array}{r}20,480 \\
20\end{array}$ \\
\hline 71 & $\begin{array}{ll}\text { H } & 1,6,7(35) \\
\text { H } & 1,6,7 \text { absorbed by } 71\end{array}$ & $\begin{array}{r}10,240 \\
160\end{array}$ & $\begin{array}{r}20,480 \\
20\end{array}$ \\
\hline $79 R$ & $\begin{array}{ll}\text { H } & 1,3,11 \text { (S39) } \\
\text { H } 1,3,11 \text { absorbed by } 79 R\end{array}$ & $\begin{array}{r}10,240 \\
<20\end{array}$ & $\begin{array}{r}10,240 \\
\quad<20\end{array}$ \\
\hline 184 & $\begin{array}{l}\text { H } 31(1106-55) \\
\text { H } 31 \text { absorbed by } 184 \\
\text { H } 29(16019) \\
\text { H } 29 \text { absorbed by } 184\end{array}$ & $\begin{array}{r}2,560 \\
20 \\
40,960 \\
40\end{array}$ & $\begin{array}{r}5,120 \\
20 \\
40,960 \\
<20\end{array}$ \\
\hline 766 & $\begin{array}{l}\text { H } 33 \text { (466-52) } \\
\text { H } 33 \text { absorbed by } 766 \\
\text { H } 28 \text { (PC110) } \\
\text { H } 28 \text { absorbed by } 766\end{array}$ & $\begin{array}{r}40,960 \\
20 \\
81,920 \\
320\end{array}$ & $\begin{array}{r}81,920 \\
20 \\
20,480 \\
40\end{array}$ \\
\hline
\end{tabular}

${ }^{a}$ Parentheses enclose the identification number of the homologous strain.

$b$ Titer is expressed as the reciprocal of the dilution of antiserum giving a definite agglutination.

TABLE 4. Antigenic formulas assigned to the eight new Arizona serotypes

\begin{tabular}{|c|c|c|}
\hline & Strain no. & Antigenic formula \\
\hline $\begin{array}{r}1035 \\
921 \\
970 \\
1099 \\
71 \\
79 \mathrm{R} \\
184 \\
766\end{array}$ & 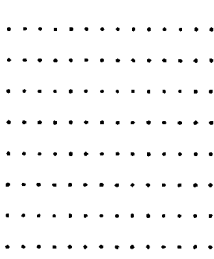 & $\begin{array}{l}1,4: 16,17,18 \\
6: 1,7,8 \\
10 \mathrm{a}, 10 \mathrm{~b}: 16,17,18 \\
19: 17,20 \\
5: 1,6,7 \\
22: 1,3,11 \\
28: 29: 31 \\
24: 33: 28\end{array}$ \\
\hline
\end{tabular}

tests to identify the $\mathrm{O}$ and $\mathrm{H}$ antigens of these strains are presented in Tables 2 and 3. From the resultant antigenic formulas, it is evident that each of these eight strains belongs to a new serotype (see Table 4).

These strains have been referred to the Enterobacteriology Unit, Center for Disease Control, Atlanta, Georgia, and the results have been confirmed.

\section{REPRINT REQUESTS}

Address requests for reprints to: Dr. Billie $O$. Blackburn, U.S. Department of Agriculture, Animal and Plant Health Inspection Service, Veterinary Services, P.O. Box 70, Ames, Iowa 50010.

1. Edwards, P. R., and W. H. Ewing. 1962. Identification of Enterobacteriaceae. Burgess Publishing Company, Minneapolis, Minn.

2. Ewing, W. H. 1969. Arizona hinshawii comb. nov. Int. J. Syst. Bacteriol. 19: 1 .

3. Ewing, W. H., and B. R. Davis. 1970. Media and tests for differentiation of Enterobacteriaceae, p. 1-22. U.S. Dept. of Health, Education and Welfare, Public Health Service, National Communicable Disease Center, Atlanta, Ga.

4. Ewing, W. H., M. A. Fife, and B. R. Davis. 1965. The biochemical reactions of Arizona arizonae, p. 1-27. U.S. Dept. of Health, Education and Welfare, Public Health Service, National Communicable Disease Center, Atlanta, Ga.

5. Kauffmann, F., and P. R. Edwards. 1952. Classification and nomenclature of Enterobacteriaceae. Int. Bull. Bacteriol. Nom. Taxon. 2: 2-8.

6. Kauffmann, F., and A. Peterson. 1956. The biochemical group and type differentiation of Enterobacteriaceae by organic acids. Acta Path. Microbiol. Scand. 38:481-491. 